\title{
コレステロール代謝に及ぼすトレーニング 期間の影響
}

$\begin{array}{llll}\text { 広 } & \text { 田 } & \text { 公 } & \text { - (日本体育大学体育研究所) } \\ \text { 坂 } & \text { 元 } & \text { 晃 } & \text { 史 (昭和大学薬学部) } \\ \text { 武 } & \text { 井 } & \text { 信 } & \text { 子(筑波大学基礎医学系) } \\ \text { 東 } & & \text { 惪 } & \text { 彦 (筑波大学基礎医学系) }\end{array}$

Effect of physical training period on cholesterol metabolism

\author{
Koichi Hirota ${ }^{1}$ \\ Terufumi Sakamoto² \\ Nobuko Takeis \\ Tokuhiko Higashis
}

\begin{abstract}
Male Wistar rats, 5-6 weeks of age and about $150 \mathrm{~g}$ of body weight, were trained for 3,6 or 10 weeks according to a treadmill running program: $15 \mathrm{~m} / \mathrm{min}, 1,000 \mathrm{~m} / \mathrm{day}$ and 6 days/week.

Compared with sedentary control rats, the trained rats gave following results:

1. Remarkable decrease in body weight,

2. Significantly lower level of serum cholesterol,

3. Relative increase in lipids loaded on $\alpha$-lipoproteins, and

4. Distinct enhancement of the incorporation of ${ }^{14} \mathrm{C}$-acetate into liver cholesterol when assayed with slices.

These manifestations became more and more obvious as the training continued for longer periods, and the differences between the trained and the sedentary rats were statistically significant after 10week exercise.

The present evidence has provided an additional support to our hypothesis that the physical exercise promotes the turnover of cholesterol in tissues.

(Koichi Hirota, Terufumi Sakamoto, Nobuko Takei and Tokuhiko Higashi, "Effect of physical training period on cholesterol metabolism", Jap. J. Phys. Educ., 30-4 : 273-79, March, 1986)

1 Nippon College of Physical Education, Institute of Physical Education, Fukazawa, Setagaya-ku, Tokyo (158)

2 Showa University, School of Pharmaceutical Sciences, Hatanodai, Shinagawa-ku, Tokyo (142)

3 University of Tsukuba, Institute of Basic Medical Sciences, Sakura-mura, Nihari-gun, Ibaraki-ken (305)
\end{abstract}


動脈硬化の予防につながるであろうとされてい る身体運動の奻果のメカニズムを解明する一助に 資せんとして，著者らはさきにWistar 系雄ラッ トに5-6 週の運動負荷の実験を行い，1）血清 レステロール值の低下，2）肝コレステロール量の 减少，3） ${ }^{14} \mathrm{C}$-酢酸の肝コレステロールへの in vivoでの取りこみの增加，といら成裤をえてこれ を報告し ${ }^{15)}$ ，このような訮におけるコレステロー ル代謝の六進が，動脈硬化予防上有益な現象であ ろらと考察した。

このよらな身体運動のトレーニング奻果が，運 動が長期にわたるほど顕著になるかどうかを確認 する目的で, 本研究では前回よりやや強い運動を それぞれ 3，6，10䢙負荷したラットについて，そ れぞれ同期の非置動群対照ラットと比較しながら コレステロール代謝への影響を検討した。今回は 前回の測定項目に加光，新たに，1）HDL コレス テロール量 (High Density Lipoprotein-cholesterol），2）血清リポタンパク質の電気泳動像，3） 肝切片 (in vitro) でのコレステロール生合成を测 定した。

\section{实 酸 方 法}

\section{1. 实䟻来件}

前報 ${ }^{15)}$ 之同様に生後 $5-6$ 週, 体重 $150 \mathrm{~g}$ 前後の Wistar 系雄ラットに，treadmill を用いて毎分 15 $\mathrm{m}, 1$ 日 $1,000 \mathrm{~m}, 1$ 週 6 日間の運動を課し， 3，6， 10週のトレーニング終了後以下の測定を行った。 普通食同条件下で同じ期間飼育したラットを対照 群とし，実検群と同時に湘定に供した。

\section{2. 渭定}

血清総および遊崔コレステロールはZak 法35)

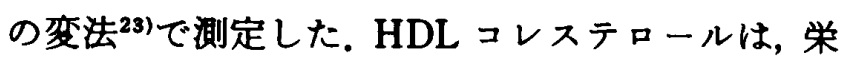
研化学の HDL コレステロール測定用キットを使 用した。本法はリンタングステン酸を含む沈筑試 薬により HDL 以外のリポタンパクを沈没さ せ5)，上清に残存する HDL のコレステロールを酵 素法2で測定するすのであるが，ヒト血清用に開 発された同キットがラットでも同様の分離奻果を 示すかどらかを予めチェックしだ3)。また同時に 酵素法で総コレステロールを定昷し，HDLコレ
ステロールの総コレステロールに対する百分率を 計算した。

血清リポタンパクの電気泳動は Naito24)の方法 に従い,ポリアクリルアミドゲルディスク䉓気泳 動法と，Sudan Black Bによる脂質の前染色法を 組合せた。泳動後デンシトメーター（富士理研， FDA IV 型）によって各リボタンパク分画の積分 比を求めた。

in vitroにおけす への取りこみは次のようにして測定した。すなわ

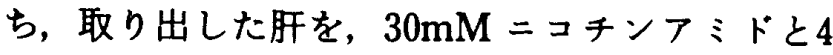
$\mathrm{mMMgCl}_{2}$ を含む0.1M リン酸カリウム緩衙液 （pH 7.4）で洗浄し，肝切片を作り，その $1.5 \mathrm{~g}$ 同綬䘖液 $15 \mathrm{ml}\left(6 \mu \mathrm{Ci}\right.$ の $^{14} \mathrm{C}$-酢酸を添加したもの) とともに, $37^{\circ} \mathrm{C}, 90$ 分間, 振盗しつつインキュベー トした。終了後, 氷浴中で冷却し, $15 \% \mathrm{KOH}(90 \%$ エタノール溶液)を $15 \mathrm{ml}$ 加え, $70^{\circ} \mathrm{C}$ の温浴中で30 分間ヶン化し, 放冷後 $20 \mathrm{ml}$ 石油エーテルで 6 回抽 出した。集めた石油エーテル居を蒸発乾固しェタ ノール $21 \mathrm{ml}$ に溶かし、アセトン $18 \mathrm{ml}$ を入れたフ ラスコ中に綿栓濾過した。濾液 $5 \mathrm{ml}$ を取り, ジギト ニンを加えて $37^{\circ} \mathrm{C} に 一$ 夜放置し，沈澱したコレス テロールの放射能を液体シンチレーションカウン ターで測定した。

なお，測定値の日内変動勇をさけるために，ラッ トを殺す時刻が午後 1 時前後になるよ5に配虑し た。

\section{实 的莫 果}

\section{1. 体五}

測定時の両群ラットの体重を比較したのが Table 1である．対照群は 3-10週と日時の経過 とともに体重が漸増したが，罣動群ではその増加 が少で，6週運動ラットと10週運動ラットの間 には差がなく，どの時期においても運動群の体重 は対照群に対して有意に小さかった。

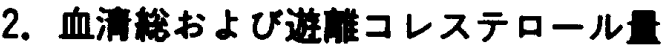

運動群および対照群各 5-9 例の血清コレステ ロール剆定値を Table 2に示す。

平均值は何れも運動群の方が低值で， 6 週の遊 離コレステロールと，10週の総コレステロールお 
Table 1. Body weight of rats (g).

\begin{tabular}{lcccc}
\hline \multirow{2}{*}{ Group } & \multicolumn{5}{c}{ Period for exercise (weeks) } \\
\cline { 2 - 5 } & 0 & 3 & 6 & 10 \\
\hline Exercise & $201 \pm 10.5(21)$ & $318 \pm 27.1(8)$ & $388 \pm 28.2(8)$ & $397 \pm 33.8(5)$ \\
Control & $204 \pm 14.6(20)$ & $353 \pm 23.4(6)$ & $420 \pm 27.2(5)$ & $516 \pm 21.3(9)$ \\
\hline p & N.S. & $<0.05$ & $<0.05$ & $<0.001$ \\
\hline
\end{tabular}

Figures are the average \pm standard deviation, and those in parentheses inducate the number of animals.

Table 2. Level of total and free chrolesterol in serum $(\mathrm{mg} / 100 \mathrm{ml})$ : Zak's Method.

\begin{tabular}{lllccc}
\hline \multirow{2}{*}{ Cholesterol } & \multirow{2}{*}{ Group } & \multicolumn{3}{c}{ Period for exercise (weeks) } \\
\cline { 3 - 6 } & & 3 & 6 & 10 \\
\hline \multirow{2}{*}{ Total } & \multirow{2}{*}{ (T) } & Exercise & $56.1 \pm 10.2(8)$ & $66.1 \pm 8.0(8)$ & $57.7 \pm 3.2(5)$ \\
& & Control & $66.5 \pm 7.3(6)$ & $72.9 \pm 5.4(5)$ & $83.1 \pm 7.3(9)$ \\
\cline { 3 - 6 } & & $\mathrm{p}$ & N.S. & N.S. & $<0.001$ \\
\hline \multirow{2}{*}{ Free } & \multirow{2}{*}{ (F) } & Exercise & $16.3 \pm 2.1(8)$ & $13.4 \pm 1.7(8)$ & $11.1 \pm 1.1(5)$ \\
& & Control & $18.6 \pm 3.5(6)$ & $17.2 \pm 2.0(5)$ & $19.2 \pm 2.6(9)$ \\
\cline { 3 - 6 } & & p & N.S. & $<0.01$ & $<0.001$ \\
\hline \multirow{2}{*}{ Ester } & \multirow{2}{*}{ (T-F) } & Exercise & 39.8 & 52.7 & 46.6 \\
& & Control & 47.9 & 55.7 & 63.9 \\
\hline
\end{tabular}

N.S. : not significant.

よび遊離コレステロールの值に有意差が認められ た.

エステル型コレステロールを総コレステロール と遊離コレステロールとの差として平均值から計 算したが，何れす運動群が低值で，とくに10週運 動群で対照群に比してかなり低い値を示した点が 注目された。

対照群においては，総コレステロールが加龄に 伴って増加する傾向がみられ，しかるそれがェス テル型コレステロールの増加に起因している.こ れに対して運動群では，10週運動ラットの血清コ レステロール旦が 6 週運動ラットのそれよりも有 意に低值を示し，とくにエステル型コレステロー ルの減少が明らかであった。

\section{HDL コレステロール}

栄研キットを用いた酵莱法による HDL コレス テロールおよび総コレステロールの測定值ならび に両者の比の値を Table 3に示す.

総コレステロール值は, Table 2の Zak 変法に
よる測定值との間に多少の相違が認められるが, 何れも運動群が低值で，10週運動群ではとくに対 照群との差が大きかった。

HDL コレステロールは，6 週まで, 両群とすに あまり変動しなかったが，6ー10週の間に対照群 で増加し，運動群に比べて有意に高値となった。

動脈硬化発症の 1 つの指標とされている HDL コ レステロールの総コレステロールに対する割合を みると，運動群が実験期間を通じてはほ $60 \%$ 前後 を維持していたのに対し，対照群ではそれより低 く50\%前後で，特に 6 週から10週にかけては，対 照群では HDL コレステロールの增加 (4mg)より も総コレステロールの増加 (19.8mg)の方が大き くこの比率は $50 \%$ を割った。

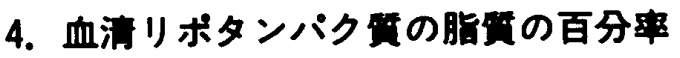

龟気泳動分析で分画した $\alpha$ ・リポタンパク質と (pre $\beta+\beta)$ リボタパク質に含まれる脂質の百 分率はTable 4のとおりで，対照群では実馀期間 を通じてほとんど变動がなかったのに対し，運動 
Table 3. Level of HDL- and total cholesterol (mg/100ml serum) : enzymatic method.

\begin{tabular}{llccc}
\hline \multirow{2}{*}{ Cholesterol } & Group & \multicolumn{3}{c}{ Period for exercise (weeks) } \\
\cline { 2 - 5 } & & 3 & 6 & 10 \\
\hline \multirow{2}{*}{ HDL } & Exercise & $35.4 \pm 2.9(8)$ & $36.1 \pm 3.1(8)$ & $34.1 \pm 2.8(5)$ \\
& Control & $36.9 \pm 3.7(6)$ & $36.9 \pm 3.5(8)$ & $40.9 \pm 2.9(9)$ \\
\cline { 2 - 5 } & $\mathrm{p}$ & $\mathrm{N} . \mathrm{S}$. & $\mathrm{N} . \mathrm{S}$. & $<0.001$ \\
\hline \multirow{2}{*}{ Total } & Exercise & $60.8 \pm 8.1(8)$ & $60.2 \pm 7.1(8)$ & $53.9 \pm 3.5(5)$ \\
& Control & $70.9 \pm 7.2(6)$ & $67.2 \pm 4.9(5)$ & $87.0 \pm 7.8(9)$ \\
\cline { 2 - 5 } & $\mathrm{p}$ & $<0.05$ & $\mathrm{~N} . \mathrm{S}$. & $<0.001$ \\
\cline { 2 - 5 } HDL/Total & Exercise & $0.58 \pm 0.04(8)$ & $0.60 \pm 0.03(8)$ & $0.63 \pm 0.03(5)$ \\
& Control & $0.52 \pm 0.03(6)$ & $0.55 \pm 0.03(5)$ & $0.47 \pm 0.03(9)$ \\
\cline { 2 - 5 } & $\mathrm{p}$ & $<0.05$ & $<0.05$ & $<0.001$ \\
\hline
\end{tabular}

N.S. : not significant

Table 4. Relative concentration of lipids in $\alpha$-lipoprotein to those in (pre $\beta+\beta) \cdot$ lipoprotein $(\%)$.

\begin{tabular}{cccc}
\hline \multirow{2}{*}{ Group } & \multicolumn{3}{c}{ Period for exercise (weeks) } \\
\cline { 2 - 4 } & 3 & 6 & 10 \\
\hline Exercise & $74.5 / 25.5 \pm 3.2(8)$ & $74.6 / 25.4 \pm 5.5(8)$ & $77.5 / 22.5 \pm 2.5(5)$ \\
Control & $73.1 / 26.9 \pm 1.7(6)$ & $73.4 / 26.6 \pm 5.8(5)$ & $73.4 / 26.6 \pm 2.6(9)$ \\
\hline p & N.S. & N.S. & $<0.01$ \\
\hline
\end{tabular}

Lipoproteins were stained for their lipids with Sudan Black B and assayed densitometrically.

Figures are the percentage of $\alpha /($ pre $\beta+\beta)$-lipoprotein to the sum of both.

N.S. : not significant.

Table 5. Incorporation of ${ }^{14} \mathrm{C}$-acetate into liver cholesterol in vitro (cpm/mg cholesterol).

\begin{tabular}{cccc}
\hline \multirow{2}{*}{ Group } & \multicolumn{4}{c}{ Period for exercise (weeks) } \\
\cline { 2 - 4 } & 3 & 6 & 10 \\
\hline Exercise & $7,279 \pm 2,262(8)$ & $14,532 \pm 3,278(7)$ & $33,903 \pm 3,623(5)$ \\
Control & $3,707 \pm 941(8)$ & $3,398 \pm 786(5)$ & $4,002 \pm 924(9)$ \\
\hline p & $<0.001$ & $<0.001$ & $<0.001$ \\
\hline
\end{tabular}

Liver slices were incubated at $37^{\circ}$ for 90 minutes with ${ }^{14} \mathrm{C}$-acetate.

群では10週後に $\boldsymbol{\alpha}$-リボタンパク質の割合が増加 し, 同週令の対照群との間に有意差が認められた。

\section{5. 肝切片のコレステロール合成能}

肝切片を用い, ${ }^{14} \mathrm{C}$-䣫酸のコレステロールへの 取り込み（90分インキュベーション）を測定した 結果を Table 5に示す。

対照ラットでは実験期間中加龄に伴ら変動を示
さなかったが，運動群では 3 週ですでに対照の 1.96 倍の比放射能が観察され，さらに 6 週で4.28 倍，10週では8.47倍に達し，運動が長期にわたる 程著明な取りこみ増が認められた。

\section{6. 統到的模定法}

結果の数值に関し，運動群と対照群との間の有 意性の統計的検定はStudent の t-test 法により 
行った。

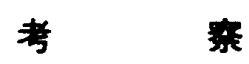

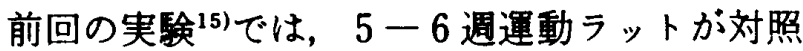
群との間に体重の差を示さなかったが，今回の実 倹では運動群が常に有意に軽量で，とくに10週運 動群では対照群との間に歴然とした差が観察され た。その後の著者らの実験(未発表)で同週龄ラッ トに同程度の運動を 8 週負荷した例でも，体重は 有意に対照群より少ないことが確認されている。

最近, Deshanies et $\mathrm{al}^{8)}$ ，強制的に泳がせた Wistar 系雌ラットで, 同じ結果を報告している。 飼料摄取量は体重の増减と深い関わりをむつ。本 実験に打いては運動群にその摄取が大きかった が，粉食で食べちらかしがあったため摄取量は正 しく計量することができなかった。ちなみにわれ われが 7 週龄の SHRSP ラットで同様の運動負

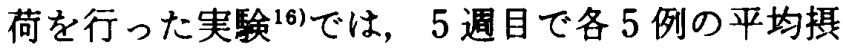
取量が運動群 $146 \pm 10 \mathrm{~g} /$ 週, 対照群118 $\pm 12 \mathrm{~g} /$ 週, 10週目ではそれぞれ128士12g/週と $120 \pm 10 \mathrm{~g} /$ 週 であり，5週目の摂取量は運動群の方が有意に多 かった。

前回の実験条件下では，血清総コレステロール については有意の差がみられなかったが，今回は 10週運動群が対照に比して有意に低值を示した。 運動の強度と持続とが増加するにつれて，血清総 コレステロール量低下の効果が出現するすのと解 される。.上記 Deshanies et al. ${ }^{8)}$ の実験では，1日 2 時間, 1 週 5 回, 4 週間の遊泳では血清総コレ ステロール值は不変であったという。しかし，

Gollnick et al. ${ }^{12)}$ によるラット遊泳トレーニン グでは血浆コレステロールの減少が観察されてい る。因みにヒトにおいて，運動のトレーニング効 果として血清コレステロール值が低下したという 報告は, Lopez-s, et . al. ${ }^{20)}$, Cooper et $\mathrm{al}^{7}$, Peltonen ${ }^{27)}$ ，あるいは Dressendorfer')などの論文 が挙げられるが，他方影䇾がなかったといら報告 るかなりの数に見受けられる11,11,21),28),32),331,35). 恐 らくは, Campbell'p, Papadopoulon et al. ${ }^{26)}$ が 示唆しているよらに，運動の種類や強度が関与す るのであろ5。
血清遊離コレステロールは，前回同様，今回の 実験でも，運動 6 週および10週のラットも対照群 より有意に低いことが知られた。

HDL コレステロールの絶対值は本実輍ではむ しろ運動群で低いが，動脈硬化発症の指標之目さ れている HDLコレステロール/総コレステロー ルの比の值は，平均値から計算したかぎりでは運 動群の方が高く（Table 3），とくに10週運動群に おいて著明であった. Deshanies ${ }^{8)}$ の実験例でも この比の值が $15 \%$ 増加したいう。ヒトではトレー ニングの結果として HDL コレステロールの増加 や，HDL コレステロールの総コレステロールに 対する比率の増加を報告した例(1),99,10),18),21),22),25)。 27),281,29),31),32),33),34)が多いが，一方また HDL コレス テロールが変化しないという Frey et al. $^{1{ }^{11} や}$

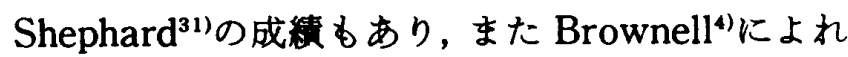
ば，27一57歳の男女の，70\% HR $\max て ゙ 1$ 日 15-25分，10週間のトレーニングの結果，男子で は HDL コレステロールが増加したのが，女子で はむしろ低下したいう，さらに Lehtonen ${ }^{19)}$ aerobicの練習をしたサッカーの選手では HDL コレステロールは高值を示したが anaerobicの 練習をしたアイスホッケーの選手ではむしろ対照 より低值であったとの報告すある。

Table 4の数值は， $\alpha$-リポタンパク質に含有さ れる脂質と， $\boldsymbol{\beta}$ ・リポタンパク質に含有されている 脂質との割合を示するのである，前者が HDL，後 者が LDL にほぼ対応することと，両者の脂質の 中でュレステロールの占める比率が高いことを考 え合わせると, 運動10週後のラットで, HDL コレ ステロール/LDL コレステロールの相対比が対照 よりす上㫒していることが示唆される．第 3 表で 総コレステロールと HDL コレステロールの差を LDL コレステロールとすれば, 10週運動群で19.8 同対照群で46.1mg/100ml 血清となり，明らかに 前者が低い，ヒトのトレーニング効果に関する上 掲の論文の中でも, LDL コレステロールが対照に 比して低いといら報告が多いが(4),27),29),32),34), Adner ${ }^{11}$ の実験では差が認められていない。

前回の実検 ${ }^{15}$ において，運動群ラットにおいて 肝コレステロール量が少い上に, in vivo での ${ }^{14} \mathrm{C}$ - 
酢酸による標識速度が大きいことを報告したが， 今回は肝切片を用いて in vitro で運動群ラットの コレステロール生合成能が極めて六進しているこ とを立証した。これはコレステロール生合成の鍵 酵素である HMG-CoA reductase の活性增加に 関連していることがその後の著者らの研究で明ら かになっている (未発表)，従って前報で考察した ように，運動群において肝のコレステロール代謝 の六進があることはほぼ確実であろら。 Hebbelinck $^{14)}$ はマウスに運動を負荷し，6日以後 にコレステロール代謝の元進がみられたと報告し ており，また Lampman et al. ${ }^{177}$ オンニング実験 12週のラットで, 肝ュレステロールの減少と ${ }^{14} \mathrm{C}$ 酭酸の取りこみ増加といら，われわれと同じよう な成績を得ている。

以上を総合して「ラットに運動を負荷したト レーニンク奻果として，コレステロールの代謝回 転が促進される」といら前報の結論が本研究にお いてもさらに立証されるすのと考えられるが，一 方そのような奻果が発現するためにはある程度, 長期にわたる運動負荷が必要であることが改めて 示唆された.すなわち今回の測定項目についてみ ても， 3 週間の運動負荷では体重と，肝切片での コレステロール生合成の 2 項目だけしか有意差が 認められず，6 週間運動負荷ではこれらの他にわ ずかに血清遊離コレステロール量での有意差が加 わるのみであるが，10週運動負荷ではすべての測 定項目において対照群との間に明らかな有意差が 認められている。

\section{桔給}

運動が動脈硬化の予防の上にもつ効果のメカニ ズムを解明する一助に資せんとして, Wistar 系雄 ラットにそれそれ 3，6，10週間の強制運動を負 荷し、コレステロール代謝への影䇾を锶察した。

その結果, 運動負荷の期間が長くなればなる程, 体重の減少，血清コレステロール値の低下，血清 $\alpha$-リボタンハクク脂質の相対的増加, 肝のコレステ ロールヘの ${ }^{14} \mathrm{C}$-酢酸の取りこみ六進（in vitro）が 明瞭に認められるようになり，運動のトレーニン グ奻果としてコレステロールの代謝回転の促進が
示唆された。

$$
\text { 文献 }
$$

1) Adner, M.M. and Castelli, W.P., "Elevated highdensity lipoprotein levels in marathon runner," J.A.M. A., 243 : 534-36, 1980.

2) Allain, C.C., Poon, L.S., Chan, C.S.G., Richmond, W. and Fu, P.C., "Enzymatic determination of total serum cholesterol", Clin. Chem., 20 : 470-75, 1974.

3) Bortz, W.M. and Steele, L.A., "Synchronization of hepatic cholesterol synthesis, cholesterol and bile acid content, fatty acid synthesis and plasma free fatty acid levels in the fed and fasted rat," Biochim. Biophys. Acta, $306:$ : 85-94, 1973.

4) Brownell, K.D., Bachorik, P.S. and Ayerle, R.S., "Changes in plasma lipid and lipoprotein levels in man and woman after a program of moderate exercise," Circulation, 65 : 477-84, 1982.

5) Burstein, M., Scholnick, H.R. and Morfin, R., "Rapid method for the isolation of lipoproteins from human serum by precipitation with polyanions", J. Lipid Res., 11 : 583-95, 1970.

6) Campbell, D.E., "Influence of several physical activities on serum cholesterol concentrations in young men," J. Lipid Res., 6 : 478-80, 1965.

7) Cooper, K.H., Pollock, M.L., Martin, R.P., White, S. R., Linnerud, A.C. and Jackson, A., "Physical fitness levels vs. selected coronary risk factors," J.A.M.A., 236 : 244-49, 1977.

8) Deshanies, V., Leblanc, J. and Richard, D., "Influence of a palatable, high-fat diet, and exercise training on the high-density lipoprotein to total cholesterol ratio in the rat," Metabolism, $32: 62-65$, 1983.

9) Dressendorfer, R.H., Wade, C.E., Hornick, C. and Timmis, C., "High-density lipoprotein-cholesterol in marathon runners during a 20-day road race," J.A.M. A., $247:$ 1715-17, 1982.

10) Erkelens, D.W., Albers, J.J., Hazzard, W.R., Frederick, R.C. and Bierman, E.L., "High-density lipoprotein-cholesterol in survivors of myocardial infanction," J.A.M.A., 242 : 2185-89, 1979.

11) Frey, M.A., Doerr, B.M., Laubach, L.L., Mann, B.L. and Glueck, C.J., "Exercise does not change highdensity lipoprotein cholesterol in woman after ten weeks of training," Metabolism, 31 : 1142-46, 1982.

12) Gollnick, P.D. and Simmons, S.W., "Physical activity and liver cholesterol," Intern. Z. angew, Physiol. einschl. Arbeitsphysiol., 23 : 322-30, 1967.

13）浜登道子・坂元晃史・東 息彦・国井一・质田公一 「実検的動质硬化症におけるコレステロール代謝の研究」 生物物理化学, $26 ： 235-42,1982$. 
14) Hebbelinck, M. and Casier, H., "Effect of muscular exercise on the metabolism of $4 .{ }^{14} \mathrm{C}$ labelled cholesterol in mice," Intern. $Z$. angew. Physiol. einschl. Atbeitsphysiol., 22 : 185-89, 1966.

15）厷田公一・東 輿彦・新木敏正 - 北 博正 - 井川正治 「コレステロール代懒に及ぼす身体運動のトレーニッ゙ク 奻果」体育学研究, $24: 325-32,1980$.

16）広田公一・坂元晃史 - 福田芳郎 - 東 隹彦・安部孝 「コレステロール代謝に及ぼす身体トレーニングおよび 食塩負荷の影 (第二報)。脳卒中易発症ラット (SHRSP) の場合」昭和59年度科研頶補助金研究成果報 告（\#58380011）39-46, 1985.

17) Lampman, R.M., Foss, M.L., Block, W.D. and Flora, J.D., "Metabolic adaptation with physical training : ${ }^{14} \mathrm{C}$-acetate incorporation into tissue lipids," Metabolism, 25 : 1601-09, 1976.

18) Lehtonen, A., Viikari, J. and Ehnholm, C., "Effect of exercise on high-density lipoprotein apoproteins," Acta Physiol. Scand., 106 : 487-88, 1979.

19) Lehtonen, A. and Viiari, J., "Serum lipids in soccer and icehockey players," Metabolism, $29: 36-39,1980$.

20) Lopez-S.A., Viral, R., Balart, L. and Arroyave, G., "Effect of exercise and physical fitness on serum lipids and lipoproteins," Atherosclerosis, $20: 1-9,1974$.

21) Marniemi, J., Dahlstrom, S., Kvist, M., Seppanen, A. and Hietanen, E., "Dependence of serum lipid and lecithin : cholesterol acyltransferase levels on physical training in young men," Eur. J. Applied Physiol., 49: 25-35, 1982.

22) Moore, C.E., Hartung, G.H., Mitchell, R.E., Kappus, C.M. and Hinderlitter, J., "The relationship of exercise and diet on high-density lipoprotein cholesterol levels in women," Metabolism, 32: 189-96, 1983.

23）茂手木晧長・鈴木秀郎編，標準臨床検查法。医学意院， 1967. pp. 214-16.

24) Naito, H.K., Wada, M., Ehrhart, L.A. and Lewis, L. A., "Polyacrylamide-gel electrophoresis as a screening procedure for serum lipoprotein abnormalities," Clin. Chem., $19: 228-34,1956$.

25) Nikkila, E.A., Taskinen, M-R., Rehunen, S. and Harkönen, M., "Lipoprotein lipase activity in adipose tissue and skeletal muscle of runners: Relation to serum lipoproteins," Metabolism, 27 : 1661-71, 1978. 26) Papadopoulos, N.M., Bloor, C.M. and Standefer, J. C., "Effect of exercise and training on plasma lipids and lipoproteins in the rat," J. Applied Physiol., 26: 760-63, 1969.

27) Peltonen, P., Marniemi, J., Hietanen, E., Vuoriand, I. and Ehnholm, C., "Changes in serum lipids, lipoproteins, and heparin releasable lipiolytic enzymes during moderate physical training in man: A longitudinal study," Metabolism, 30 : 518-26, 1981.

28) Rotkis, T., Boyden, T.W., Pamenter, R.W., Stanforth, P. and Wilmore, J., "High density lipoprotein cholesterol and body composition of female runners," Metabolism, 30 : 994-95, 1981.

29) Schanabel, A. and Kinderman, W., "Effect of maximal oxygen uptake and different forms of physical training on serum lipoproteins," J. Appl. Physiol., 48 : 263-77, 1982.

30) Shephard, R.J., Youldon, P.E., Cox, M. and West, C., "Effects of a 6-month industrial fitness programme on serum lipoproteins," Atherosclerosis, 35: 277-86, 1980.

31) Streja, D. and Mymin, D., "Moderate exercise and high-density lipoprotein-cholesterol," J.A.M.A., 242 : 2190-92, 1979.

32) Sutherland, W.H., Woodhouse, S.P., Williamson, S. and Smith, B., "Decreased and continued physical activity and plasma lipoprotein lipids in previously trained man," Atherosclerosis, 39 : 307-11, 1981.

33) Wood, P.D., Haskell, W.L., Blair, S.N., Williams, P. T., Krauss, R.M., Lindgren, F.T., Albers, L.J., Ho, P. H. and Frarquhar, J.W., "Increased exercise level and plasma lipoprotein concentrations: A one-year, randomized, controlled study in sedentary, middle-aged man," Metabolism, 32 : 31-39, 1983.

34) Wood, P.D., Haskell, W., Klein, H., Lewis, S., Stern, M.P. and Frarquhar, J.W., "The distribution of plasma lipoproteins in middle-aged male runners, "Metabolism, 25 : 1249-57, 1976.

35) Zlatkis, A., Zak, B., Boyle, A.J. and Mich, D., "A new method for direct determination of serum cholesterol," J. Lab. Clin. Med., 41 : 486-92, 1953. 